
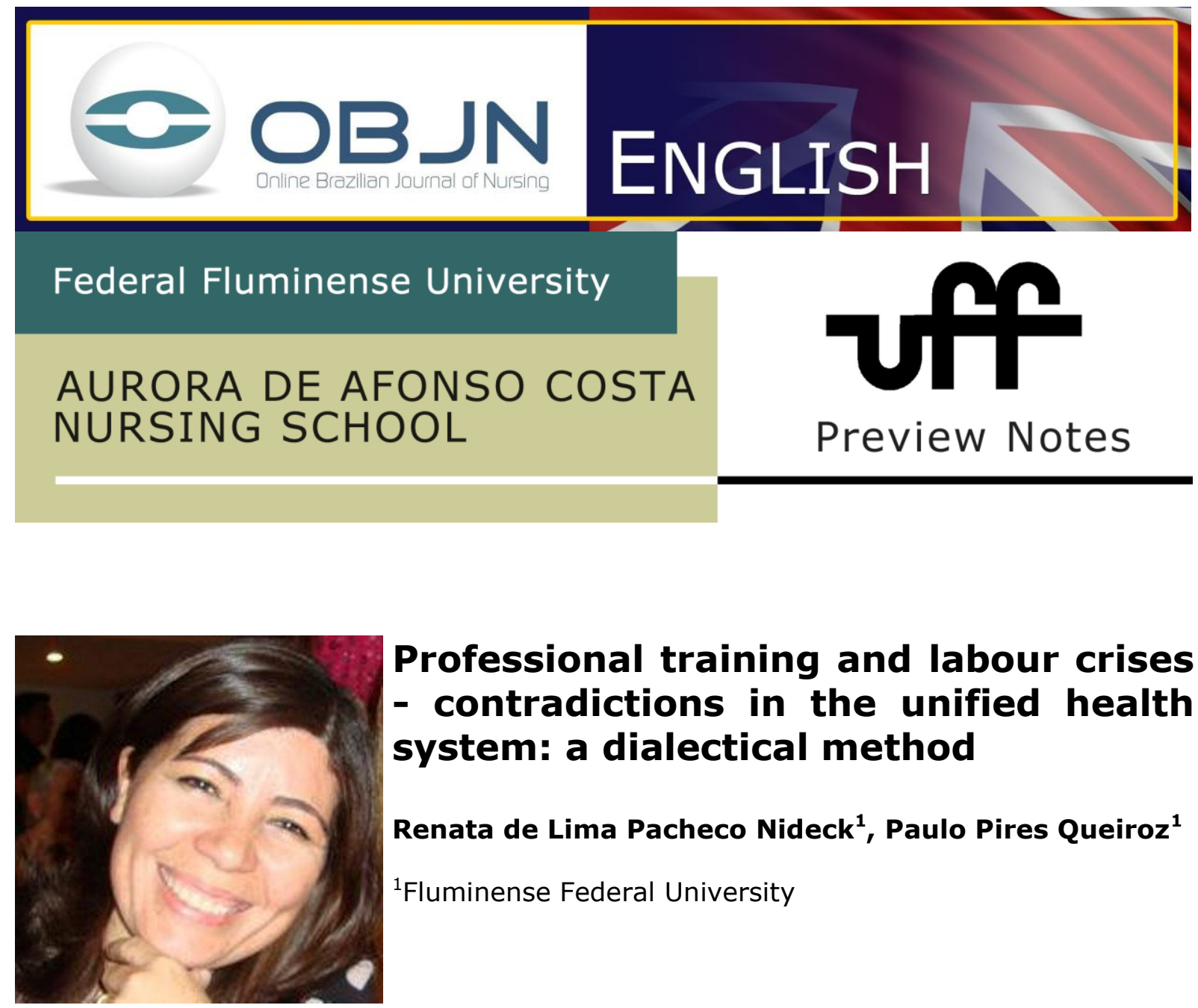

\title{
Professional training and labour crises - contradictions in the unified health system: a dialectical method
}

\author{
Renata de Lima Pacheco Nideck ${ }^{1}$, Paulo Pires Queiroz ${ }^{1}$ \\ ${ }^{1}$ Fluminense Federal University
}

\begin{abstract}
Problem: Job insecurity is a phenomenon which has a destructive character that expropriates the rights of workers which have been historically achieved. It distorts the ontological dimension of work and the quality of the services provided. These neo-liberal values have been reproduced in educational practices and thus affect the dignity of the worker in the Unified Health System (UHS). Objective: To legitimize the role of pedagogical training as a privileged locus for reflection and formulate strategies to cope with job instability in the UHS. Method: Qualitative field research in the form of action research, using the dialectical method. Scenario: Basic unit of Collective Health in Niterói. Subjects: Health professionals and trainees who are not employed as permanent public servants. According to Resolution 196/96, the ethical aspects involving the research into human beings will be respected.
\end{abstract}

Keywords: Medical Sociology, Human Resource Training, Unified Health System 


\section{PROBLEM SITUATION AND ITS SIGNIFICANCE}

Work is an essential human activity which has historical and ontological dimensions that exceed the capitalist mode of production. However, these constitutive principles of human existence contrast with the demands of a globalized world, the competitiveness of the neo-liberal model, the restructuring of productive forces and structural unemployment due to the labor crisis.

The term 'job insecurity' refers to the various mutations which have a flexible character in labor relations, service delivery, working for a specific period of time, in outsourcing, cooperatives, etc. This phenomenon implies a loss of rights, high turnover, heteronomy, employee subjection, educational indifference, social exclusion, underemployment and the weakening of the mobilization and the collective resistance of workers ${ }^{(1)}$.

In these terms, since 2006, the Ministry of Health has admitted the existence of job insecurity with regard to its professional staff. This is the result of contingent factors that have been interfering with the sustainability of the UHS. For the Ministry of Health, job instability resulted from the implementation of guidelines for the UHS, as provided for in article 198 of the Federal Constitution, regarding the decentralization of administrative and operational service networks and the integrality of actions. In this analysis, the municipalization process, along with the introduction of new public policies, promoted changes in the forms of contracting and structuring the workforce by municipalities.

By admitting the existence of job instability in the UHS through the Work Stabilization National Programme in the UHS, the Ministry of Health recognizes the need for intervention in this process. Far from transforming reality, the Improving UHS Programme prescribes, in the sphere of regulatory subjectivity, strategies for a reduction in job instability, without removing it from social relations.

The contradictions of capitalism and the labor crisis are challenges to be faced by educational institutions in building a culture of reflection, based on ethical-emancipatory values aimed at the transformation of the neo-liberal ethos in labor relations in the health sector. 
This perceived weakness is not consolidated within the work setting, when conditions for subsistence outweigh the potentialities of the worker; it emerges from the epistemological space. Thus there is the role of education in teaching emancipatory values for the subjects. It is perceived, in everyday life, that there is a need to put an end to immobility, not only in the work environment, but mainly in the dialogue between theory and practice. It is necessary that the relationship between work, education and health overcomes the logic of capital, bringing the utopia of a series of transformations for the exercise of professional activity. In this sense, we delegate to the pedagogical training the apprehension and integration of the social-political context under the hermeneutics of suspicion ${ }^{(2-3)}$. From this conversion - practice / praxis - it becomes possible to see the inequities, to develop in the student, a professional profile which is "disalienated" and to formulate counter-hegemonic strategies for coping with job instability in the $\mathrm{UHS}^{(3)}$.

\section{OBJECTIVES}

General: To legitimize the role of academic and professional training as a privileged locus for reflection and for the formulation of strategies for coping with job instability in the UHS.

Specific: To relate the political and social history of the UHS with the so-called "educational blackout" of the late 1980s and its implications for labor relations; to analyze the goals and the systematic actions of the Work Stabilization Programme in the UHS - Improving UHS Programme, and its interface with the pedagogical-professional training in the health field.

\section{METHOD}


This is a field research, of a qualitative nature, which uses the methodology of action research. The researcher and the participants will be involved in the situation in a supportive way. The theoretical and conceptual development of the research is structured on historical materialism which has been reviewed by contemporary authors. Scenario: basic unit of Niterói; the research sample will consist of 15 participants of both genders, above 18 years of age, with multi-level schooling and who are not employed as permanent public servants. By the very nature of the employment relationship in the institution, there is the possibility of a sampling decrease during the research. The importance lies in the representativeness of the analytical categories (and/or ideal types) used in the initial formulation of the problem. Exclusion criteria: commissioned positions. Data collection will be carried out through the use of unstructured interviews, testimonies and iconographic representations. The approach seeks to capture themes related to job instability: work psychopathology, vocational training and autonomy; ruptures and continuities; critical visibility of instability. The data obtained will be treated using thematic content analysis. The research project was submitted to the Ethics Committee in Research in order to fulfil the precepts of Resolution No. 196/96, and was approved according to protocol: 03255412.6.0000.5243.

\section{REFERENCES}

1. Antunes R. Os sentidos do trabalho: ensaios sobre a afirmação e a negação do trabalho. 2a ed. São Paulo: Boitempo; 2009.

2. Camargo TB, Meier MJ, Lacerda MR, Sarquis LMM. Sociopolitical knowing and healthcare workers: reflection. Online braz j nurs [serial in the internet]. 2008 [cited 2012 June 30]; Available from: http://www.objnursing.uff.br/index.php/nursing/article/view/1899

3. Santos BS. Pela mão de Alice: o social e o político na Pós-Modernidade. $12^{a}$ ed. São Paulo: Cortez; 2008.

\section{Project Data:}

This is a dissertation project of the Professional Master of Education in Health at FFU, which is approved in the Ethics Committee in Research of FFU, under no CAAE: 03255412.6.0000.5243. 
Advisor: Paulo Pires Queiroz

Research Financial Support: Ministry of Health

Mailing Address: reini@ig.com.br

Received: 01/07/2012

Approved: 04/09/2012 